\title{
Is the Service-Led Growth of India Sustainable?
}

\author{
Bharti Singh
}

\begin{abstract}
Till the decade of 1990s many studies raised doubts about the sustainability of service-led growth in India. Most often it was stated that growth in manufacturing is required to give a boost to services, employment growth, income generation, and trade balance. It is now increasingly being realized that the resilience of the Indian economy is due to the resilience of the services sector. Numerous studies since 2000s have shown that services induced growth of GDP of India is feasible. The service-led growth model is sustainable not only from the economic perspective but from social and environmental perspectives as well. To realize the maximum potential from high growth of services India should make investment in education, entrepreneurship, technology, modern means of communication and transportation, and social development. Policy reforms should be initiated to liberalise the service sub-sectors like trade (retail and wholesale), financial services, and software services that will help in faster growth through attraction of FDI. So also, labour reforms are desirable to take advantage of the demographic dividend.
\end{abstract}

Index Terms-Foreign Direct Investment (FDI), India, service sector, service sub-sectors, sustainable growth.

\section{INTRODUCTION}

It is a known fact that as a country initiates the process of economic development it experiences a structural shift. Currently it is widely accepted that with the onset of the process of economic development the secondary sector grows at a rapid rate and with the passage of time the country moves from being an agrarian economy to an advanced industrialized economy. Thereafter, there is growth of the services sector and deindustrialization takes place with the service sector as a major contributor to Gross Domestic Product (GDP) of the country. As growth took place in the currently developed economies of Europe and the North America they registered a rise in the contribution of the secondary sector in relation to the primary sector which initially is the predominant sector. With "industrialization," the secondary sector became a major contributor to GDP followed by the tertiary and primary sector and the economies transformed into developed nations in a time period of 75 to 100 years [1]. Thereafter, they registered "deindustrialiation" with the services sector as a major contributor to GDP followed by secondary and primary sector [2].

In contrast to this growth pattern, the services sector in India has grown at a rapid rate compared to the growth of the secondary sector with the onset of economic development since 1950s. In a span of 60 years, beginning from 1950-51

Manuscript received May 18, 2012; revised July 5, 2012.

Bharti Singh is with Institute of Management Technology - CDL, Ghaziabad, India (email: bhartisingh@imtcdl.ac.in; bharti0311@yahoo.com). the share of primary sector to GDP has decreased from $56 \%$ to $22 \%$ whereas the share of service sector has increased from $28 \%$ to $54 \%$. The fall in the share of the primary sector has taken 40 years that was achieved by the developed countries in 100 to 150 years and the services sector has grown at a rapid rate since 1990s [2]. The share of secondary sector has increased at a slow pace from $16 \%$ in the decade of 1950 s to only $24 \%$ in 2000s. In the decade of 2000s the share of primary, secondary and service sector were $22 \%, 24 \%$ and $54 \%$ respectively.

The stage of industrialization has been by-passed by the Indian economy with the services sector showing a phenomenal growth since the post- liberalisation period. Service-led growth in India has forced the economists to re-think about the pattern of structural shift that a country should experience as it embarks upon the path of economic development.

\section{OBSERVATIONS OF SERVICE-LED GROWTH}

The services sector of India has shown a consistent rise in GDP share and growth rate since the take-off in the journey to economic development. The share of services in GDP has risen from $28 \%$ in 1950 s to $54 \%$ in 2000s. Even the growth rate of the sector increased continuously and it has shown a high growth rate since $1980 \mathrm{~s}$ rising from $6.6 \%$ in 1980 s to $7.7 \%$ in $1990 \mathrm{~s}$ and $9.2 \%$ in $2000 \mathrm{~s}$ (Table I). Though the contribution of the secondary sector to GDP share has shown a consistent rise since 1950s the growth rate has registered a fluctuating trend. There was deceleration of industry growth in the decade of 1960s, 1970s and 1990s. The relative share of primary sector has been declining consistently since 1950s and the growth rate has shown a gradual rise since 1960s after a decline from $2.7 \%$ in 1950 s to $1.5 \%$ in 1960 s.

The contribution of services sector to GDP share has increased rapidly since the post liberalization period, that is, since 1990s. So also, the growth of services has been higher than secondary sector since 1990s. There appears to be convergence in the trend growth rates of the two sectors in 1980s thereafter services registering a higher growth than the secondary sector. The GDP share of services jumped from $44 \%$ in 1990 s to $54 \%$ in 2000 s. The trend growth rate also increased phenomenally from $7.7 \%$ in 1990 s to $9.2 \%$ in 2000s. Fig. 1 shows a comparison in the change of GDP shares of different sectors and their trend growth rate since 1950s.

This service-led GDP growth is due to high income elasticity of demand for services, use of service inputs in other sectors and rise in exports from the demand side whereas the supply side factors are trade liberalization and advanced technology [3] - [5]. High input usage of services in other sectors, economic reforms and services exports led to a 
high growth of services in 1990s [3]. Slow growth of manufacturing is another reason for this boost in the services [4], [6]. Interestingly, [7] attributes the growth in service sector in 2000 s to increase in domestic demand $(88 \%)$ rather than external demand as the fall in external demand due to global economic crisis did not lead to a sharp decline in GDP growth rate. Another notable observation has been the convergence of share of services with the international levels [8].

TABLE I: AVERAGE GDP SHARE (\%) \& TREND GROWTH RATE

\begin{tabular}{|c|c|c|c|c|c|c|}
\hline \multirow[t]{2}{*}{ Year } & \multicolumn{2}{|c|}{ Primary } & \multicolumn{2}{|c|}{ Secondary } & \multicolumn{2}{|c|}{ Tertiary } \\
\hline & $\begin{array}{l}\text { GDP } \\
\text { Share }\end{array}$ & $\begin{array}{l}\text { Gr. } \\
\text { Rate }\end{array}$ & $\begin{array}{l}\text { GDP } \\
\text { Share }\end{array}$ & $\begin{array}{l}\text { Gr. } \\
\text { Rate }\end{array}$ & $\begin{array}{l}\text { GDP } \\
\text { Share }\end{array}$ & $\begin{array}{l}\text { Gr. } \\
\text { Rate }\end{array}$ \\
\hline $1950 \mathrm{~s}$ & 56 & 2.7 & 16 & 5.8 & 28 & 4.1 \\
\hline $1960 \mathrm{~s}$ & 48 & 1.5 & 21 & 5.5 & 31 & 4.5 \\
\hline $1970 \mathrm{~s}$ & 43 & 1.8 & 23 & 4.5 & 34 & 4.6 \\
\hline $1980 \mathrm{~s}$ & 36 & 2.9 & 25 & 6.5 & 39 & 6.6 \\
\hline $1990 \mathrm{~s}$ & 29 & 3.2 & 27 & 6.2 & 44 & 7.7 \\
\hline $2000 \mathrm{~s}$ & 22 & 3.9 & 24 & 7.2 & 54 & 9.2 \\
\hline
\end{tabular}

Source: Central Statistical Organisation

Note: For 2000s decade data is from 2000-01 to 2008-09

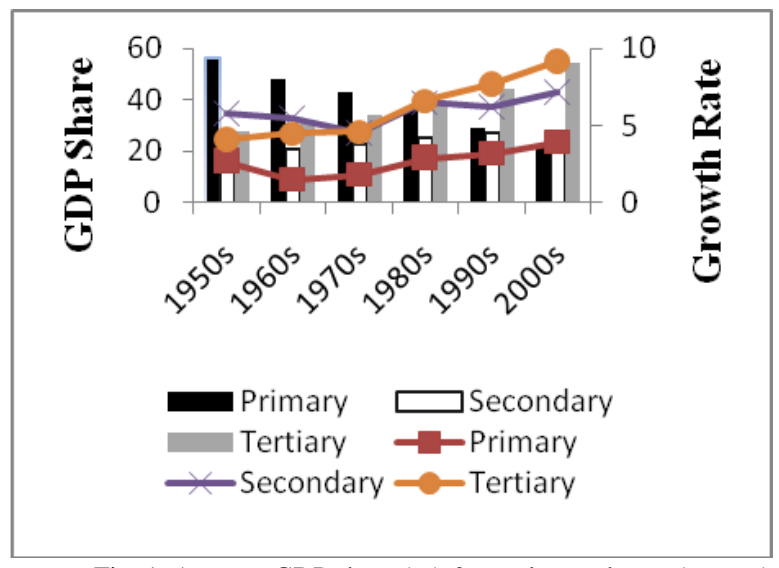

Fig. 1. Average GDP share (\%) \& trend growth rate (\% p. a.)

Since the late 1980s many studies raised apprehensions of the service-led growth of the Indian economy. Reference [9] stated that, the deviation in growth rates of the three sectors may have negative impact on inflation, balance of payments and income distribution. Since there are strong linkages from services to industry [10], [11] the growth in manufacturing sector will give an impetus to services. To enhance growth synergies among sectors relatively stronger growth of services sector is undesirable as the input demand of services sector is industry intensive rather than agriculture intensive [12]. Growth in the manufacturing sector is also desirable for trade balance and employment generation [2]. India must develop its manufacturing whose multiplier effect and impact on job creation are significant to meet the challenges of demographic profile and reduce poverty [6]. Reference [13] is of the opinion that dominance of producer services (mainly trade, transport, and financial services) show growing synergy between industry and services. Further, a $10 \%$ rise in industrial output gives rise to a $6.8 \%$ rise in services output.

\section{CONTRIbution OF SERVICE Sub-Sectors}

The contribution to GDP and growth pattern of disaggregated services has shown a fluctuating pattern. Trade, transport, communication, banking, and hotels and restaurant have shown a consistent rise in growth rate. There was a decline in the growth rate of insurance, public administration \& defense, legal services, real estate, personal services and storage from 1980s to 1990s. Their contribution to GDP in this time period has not shown a significant change except for real estate and railways (Table II). Fig 2 depicts that the growth in modern services has been high in the decade of 2000s.

\section{A. Trade}

The share of wholesale and retail trade in GDP increased from $11.9 \%$ in 1990 to $13.7 \%$ in 2000 and declined to $7.2 \%$ in 2009-10 whereas the growth rate increased from $5.9 \%$ in 1980 s to $7.3 \%$ in 1990 s and further to $8.6 \%$ in 2000 s.

\section{B. Hotels \& Restaurants}

The share of hotels and restaurants in GDP increased consistently from $0.7 \%$ in 1990 to $1.0 \%$ in 2000 and to $2.2 \%$ in 2009-10 and the growth rate also increased phenomenally from $6.5 \%$ in 1980 s to $9.3 \%$ in 1990 s and further to $10.3 \%$ in 2000s.

TABLE II: AVERAGE ANNUAL GROWTH RATE AND

GDP SHARES OF SERVICE SUB-SECTORS (\%)

\begin{tabular}{|c|c|c|c|c|c|c|}
\hline $\begin{array}{l}\text { Service } \\
\text { Sub-sectors }\end{array}$ & $\begin{array}{l}1980 \mathrm{~s} \\
\text { Growth } \\
\text { Rate }\end{array}$ & $\begin{array}{l}\text { GDP } \\
\text { share } \\
\text { in } \\
1990\end{array}$ & $\begin{array}{l}1990 \mathrm{~s} \\
\text { Growth } \\
\text { Rate }\end{array}$ & $\begin{array}{l}\text { GDP } \\
\text { share } \\
\text { in } \\
2000\end{array}$ & $\begin{array}{l}2000 \mathrm{~s} \\
\text { Growth } \\
\text { Rate }\end{array}$ & $\begin{array}{l}\text { GDP } \\
\text { share in } \\
2009-1 \\
0\end{array}$ \\
\hline Trade & 5.9 & 11.9 & 7.3 & 13.7 & 8.6 & 7.2 \\
\hline $\begin{array}{l}\text { Hotels \& } \\
\text { Restaurant }\end{array}$ & 6.5 & 0.7 & 9.3 & 1.0 & 10.3 & 2.2 \\
\hline Railways & 4.5 & 1.4 & 3.6 & 1.1 & 7.3 & 9.4 \\
\hline $\begin{array}{l}\text { Transport by } \\
\text { other means }\end{array}$ & 6.3 & 3.8 & 6.9 & 4.3 & 8.9 & 7.0 \\
\hline Storage & 2.7 & 0.1 & 2.0 & 0.1 & 2.7 & 10.7 \\
\hline Communication & 6.1 & 1.0 & 13.6 & 2.0 & 25.7 & 32.1 \\
\hline $\begin{array}{l}\text { Banking and } \\
\text { Insurance }\end{array}$ & 11.9 & 4.2 & 9.7 & 7.0 & 9.9 & 11.3 \\
\hline $\begin{array}{l}\text { Dwelling, Real } \\
\text { Estate \& } \\
\text { Business } \\
\text { Services }\end{array}$ & 10.6 & 5.1 & 12.4 & 5.6 & 8.0 & 7.5 \\
\hline $\begin{array}{l}\text { Public } \\
\text { Administration } \\
\text { \& Defense }\end{array}$ & 7.0 & 6.0 & 6.0 & 6.1 & 3.6 & 13.0 \\
\hline Other Services & 5.7 & 6.4 & 6.6 & 8.3 & 7.1 & 10.9 \\
\hline
\end{tabular}

Source: Central Statistical Organisation

Note: For 2000s data is from 2000-01 to 2008-09

\section{Railways}

The contribution of railways to GDP decreased from $1.4 \%$ in 1990 to $1.1 \%$ in 2000 and jumped to $9.4 \%$ in $2009-10$ and the growth rate also decreased from $4.5 \%$ in 1980 s to $3.6 \%$ in 1990 s and rose at a highly $9.4 \%$ in 2000 s.

\section{Transport by Other Means}

Share of road, water and air transport in GDP consistently increased from $3.8 \%$ in 1990 to $4.3 \%$ in 2000 and then almost doubled to $7.0 \%$ in $2009-10$. The growth rate also increased from $6.3 \%$ in 1980 s to $6.9 \%$ in 1990 s and further rose to $8.9 \%$ in 2000 s. 


\section{E. Storage}

The contribution of storage to GDP remained constant at $0.1 \%$ in and 1990 and 2000 and then jumped to $10.7 \%$ in 2009-10. Though the growth rate decreased from $2.7 \%$ in $1980 \mathrm{~s}$ to $2.0 \%$ in $1990 \mathrm{~s}$ it rose to $9.4 \%$ in $2000 \mathrm{~s}$.

\section{F. Communications}

The share of communication in GDP doubled from $1.0 \%$ in

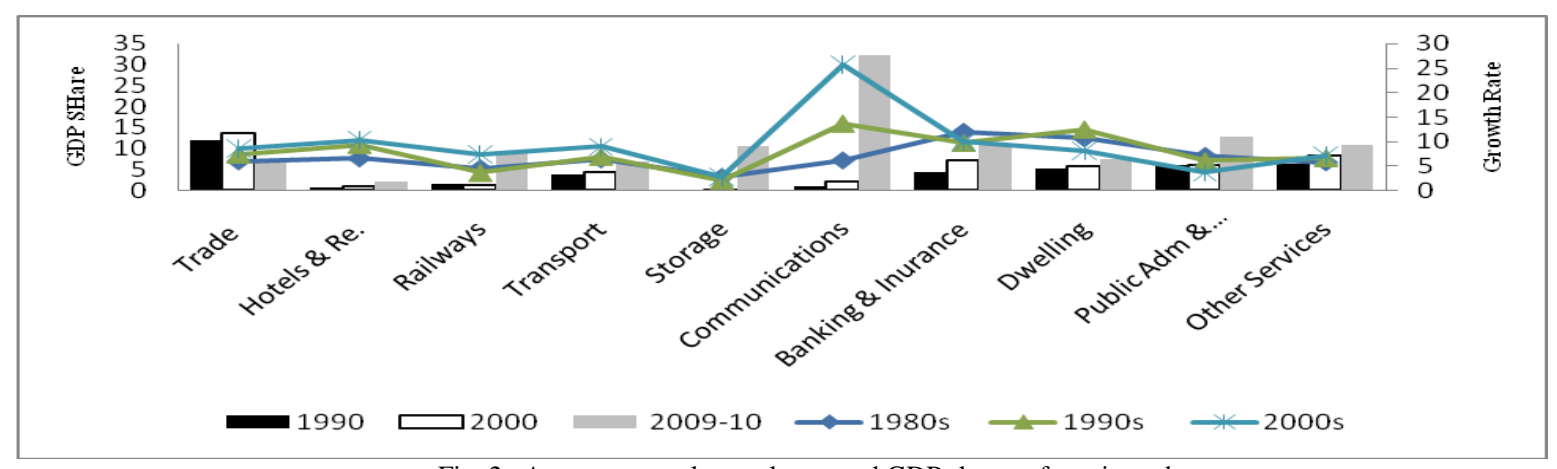

Fig. 2. Average annual growth rate and GDP shares of service sub-sectors

1990 to $2.0 \%$ in 2000 and then to $32.1 \%$ in $2009-10$. The growth rate also increased phenomenally from $6.1 \%$ in $1980 \mathrm{~s}$ to $13.6 \%$ in 1990 s and further to $25.7 \%$ in 2000 s.

\section{G. Banking \& Insurance}

The contribution of banking and insurance to GDP increased consistently from $4.2 \%$ in 1990 to $7.0 \%$ in 2000 to $11.3 \%$ in $2009-10$ whereas the growth rate has decreased from $11.9 \%$ in $1980 \mathrm{~s}$ to $9.7 \%$ in $1990 \mathrm{~s}$ and then rose marginally to $9.9 \%$ in $2000 \mathrm{~s}$.

\section{H. Dwelling Real Estate \& Business Services}

Though the contribution of dwelling real estate and business services to GDP increased consistently from $5.1 \%$ in 1990 to $5.6 \%$ in 2000 and further to $7.5 \%$ in $2009-10$, the growth rate increased from $10.6 \%$ in 1980 s to $12.4 \%$ in 1990 s and then fell to $8.0 \%$ in 2000 s.

\section{Public Administration \& Defense}

The share of public administration and defense in GDP increased consistently from $6.0 \%$ in 1990 to $6.1 \%$ in 2000 then jumped to $13.0 \%$ in $2009-10$ whereas the growth rate has decreased from $7.0 \%$ in 1980 s to $6.0 \%$ in $1990 \mathrm{~s}$ and further to $3.6 \%$ in $2000 \mathrm{~s}$.

\section{J. Other Services}

Professional services and financial services have shown a consistent rise in the share in GDP from $6.4 \%$ in 1990 to 8.3 $\%$ in 2000 then jumped to $10.9 \%$ in $2009-10$ and the growth rate has also consistently increased from $5.7 \%$ in 1980 s to $6.6 \%$ in 1990 s and further to $7.1 \%$ in $2000 \mathrm{~s}$.

Estimates of [14] show that a unit increase in trade, hotels and restaurants, transport, storage and communications leads to 0.484 units increase in services output, while a unit increase in community, social and personal services 0.272 units increase in services output and a unit increase in finance, insurance, real estate and business services 0.237 units increase in services output.

Growth of services in India has been broad-based, although it has been unusually rapid in modern services like communications, business services and services that are tradable internationally [4], [8], [15], [16]. Trade (retail \& wholesale), software services and banking services should be given an impetus as they have a higher contribution to GDP, rising domestic demand, higher growth rates and boost productivity of the manufacturing sector, thereby leading to a sectorally-linked productivity spiral [7]. Education and health care should be deregulated to meet domestic demand.

\section{TREND IN EMPLOYMENT TRADE AND ForEIGN DiRECT INVESTMENT (FDI) OF SERVICE SUB-SECTORS}

\section{A. Employment}

Share of services in employment till 1990s did not rise at the same pace as the share in GDP. The growth in employment in service sector had been low, in fact referred as "jobless" [3]. Notably, change in employment between 1993-94 and 2007-08 shows that the secondary and tertiary sector almost equally shared the gain as a shift of labour took place from the primary sector. In 2007-08 the tertiary sector provided employment to one-fourth of the total employment and secondary sector only $18.7 \%$. Primary sector still remains the largest employment provider with $55.9 \%$ of labour force employed by the sector (Table III). Service sector will provide greater employment opportunities with broad based high growth of GDP [13].

Employment elasticity of government services fell from 0.5 between $1983-84$ to $1993-94$ and to 0.07 between 1993-94 to 1999-00, whereas of financial services from 0.92 to 0.73 [4]. Business services, finance, real estate and insurance have shown highest employment elasticity (0.94) followed by trade, hotel and restaurant (0.59) and community, social and personal services $(0.28)$ in the time period of 1999-00 to 2004-05 [8].

Wholesale and retail trade, hotels and restaurants and community, social and personal services provided three-fourths of the service sector employment in India since 1980s [13], [17]. Their share in employment in the service sector in 2004 was $77 \%$ whereas contribution to output was $62 \%$. Transport, storage and communication and financing, insurance, real estate and business services - the highly productive sectors, are not able to generate adequate employment. Though their contribution to service output is approximately $34 \%$ to $38 \%$ since 1980 s their share in 
employment is between $16 \%$ to $23 \%$ (Table IV).

TABLE III: SHARE OF BROAD SECTORS IN EMPLOYMENT (USUAL PRINCIPAL AND SUBSIDIARY STATUS)

\begin{tabular}{|c|c|c|c|c|c|c|}
\hline \multirow[t]{2}{*}{ Sector } & \multicolumn{3}{|l|}{ Share $(\%)$} & \multicolumn{3}{|c|}{ Change in shares } \\
\hline & 1993-94 & 2004-05 & 2007-08 & $\begin{array}{l}2004-05 \text { over } \\
1993-94\end{array}$ & $\begin{array}{l}2007-08 \text { over } \\
2004-05\end{array}$ & $\begin{array}{l}\text { 2007-08 over } \\
1993-94\end{array}$ \\
\hline Primary & 64.5 & 57.0 & 55.9 & -7.5 & -1.1 & -8.6 \\
\hline Secondary & 14.3 & 18.2 & 18.7 & 3.9 & 0.5 & 4.4 \\
\hline Tertiary & 21.2 & 24.8 & 25.4 & 3.6 & 0.6 & 4.2 \\
\hline
\end{tabular}

TABLE IV: SHARE OF SERVICE SUB-SECTORS IN OUTPUT AND EMPLOYMENT (\%)

\begin{tabular}{|c|c|c|c|c|c|c|c|c|}
\hline \multirow[t]{2}{*}{ Year } & \multicolumn{2}{|c|}{ Trade, Hotels \& Restaurants } & \multicolumn{2}{|c|}{$\begin{array}{l}\text { Transport, Storage, \& } \\
\text { Communication }\end{array}$} & \multicolumn{2}{|c|}{$\begin{array}{c}\text { Finance, Insurance \& Real } \\
\text { Estate }\end{array}$} & \multicolumn{2}{|c|}{$\begin{array}{c}\text { Community, Social \& Personal } \\
\text { Services }\end{array}$} \\
\hline & Output & Employment & Output & Employment & Output & Employment & Output & Employment \\
\hline 1961 & 44 & 29 & 16 & 11 & 6 & 2 & 34 & 58 \\
\hline 1971 & 41 & 30 & 17 & 14 & 7 & 3 & 35 & 53 \\
\hline 1981 & 40 & 32 & 19 & 15 & 8 & 2 & 33 & 51 \\
\hline 1991 & 35 & 36 & 19 & 14 & 15 & 2 & 31 & 48 \\
\hline 2001 & 34 & 37 & 19 & 16 & 17 & 7 & 30 & 40 \\
\hline 2004 & 34 & 39 & 21 & 14 & 17 & 9 & 28 & 38 \\
\hline
\end{tabular}

Service sector employment intensity is affected by investment, public expenditure, economic structure (share of employment of the secondary and service sector) and labour market reforms [17].

TABLE V: SHARE OF SERVICES EXPORTS (\%)

\begin{tabular}{llll}
\hline \hline Year & $\begin{array}{l}\text { Share in total } \\
\text { services output of } \\
\text { India }\end{array}$ & $\begin{array}{l}\text { Share in } \\
\text { GDP of India }\end{array}$ & $\begin{array}{l}\text { World } \\
\text { services } \\
\text { Exports }\end{array}$ \\
\hline $1990-91$ & 3.2 & 1.6 & $0.6^{*}$ \\
$1995-96$ & 4.5 & 2.3 & \\
$2000-01$ & 6.9 & 3.9 & $1.2^{*}$ \\
$2005-06$ & 12.9 & 7.8 & $2.2^{*}$ \\
$2008-09$ & 15.1 & 9.4 & $3.3^{*}$ \\
\hline \hline
\end{tabular}

Source: RBI, Handbook of Statistics

\section{B. Trade}

There has been a consistent rise in service exports, especially of software and computer related services, since 1990s as shown in Table V. Increase in service exports has been due to advancement in technology and trade liberalization. Many non tradable service products became tradable due to technological improvement [6]. 'Service-led-growth strategy' - a concomitant of export-led-growth strategy has led to improvement in comparative advantage and export of commercial services during 1990 to 2005 [5].

India's exports of aggregate services to the world are more responsive to income changes (3.22) rather than to price changes (0.56) and travel exports followed by finance and transportation are most income elastic exports [7].

The share of services exports in total services output of India has risen at a greater pace since 2000s. It jumped from $6.9 \%$ in $2000-01$ to $12.9 \%$ in $2005-06$ and further to $15.1 \%$ in 2008-09. Services exports constituted $1.6 \%$ of GDP in $1990-91$ and rose by almost six times to $9.4 \%$ by $2008-09$. The share of India's services exports in world services exports rose by over five times from $0.6 \%$ in $1990-91$ to $3.3 \%$ in 2008-09 (Table V).

Software services and non software services (business, financial and communication services) constituted three-fourth of the total services exports in 2010-11. They also registered highest compound annual growth rate of $28.2 \%$ and $33.8 \%$ respectively between 2000-01 and 2008-09 (Table VI).

\section{Foreign Direct Investment (FDI)}

Since 1990s there has been an increase in share of services in inward FDI and outbound FDI. Financial and non financial services $(20 \%)$ computer hardware and software $(7 \%)$, telecommunications (8\%), housing and real estate (7\%) have attracted largest share of FDI from April 2000 to January 2012 [18]. Overseas investments were highest from the financial insurance, real estate, and business services $(39 \%)$, followed by trade, restaurants and hotels (11\%), transport, communication and storage (5\%) and community, social and personal services (4\%) in 2010-11[18].

Reference [14] shows that there is a two- way relationship between FDI and service sector output. His estimates reveal that one unit of FDI leads to 0.299 units increase in service sector output while one unit increase in service sector output increases FDI by 2.966 units. Attraction of FDI through further globalization and liberalization will increase services output that will also boost the GDP growth.

\section{Service-Led Growth And Sustainable DEVELOPMENT}

Currently it is being recognized that economic development should not only lead to a higher national GDP and better quality of life but should be environmentally sustainable as well. As the developing countries and transition economies take the path to economic development there should be an improvement in human well-being coupled by lower ecological footprint. Therefore, sustainable development has been discussed here from economic, social 
and environmental perspective.

\section{A. Economic Sustainability}

Several studies have put forward a multitude of reasons for economic sustainability. Some of them are listed here:

1) Services sector of India has the strongest impact on GDP with a 0.634 increase in GDP when there is one unit increase in GDP) and industry (0.084 units increase in GDP) in services sector as compared to agriculture (0.202 units [14]. High growth in services tends to have a stronger effect on overall economic growth than the growth in manufacturing.

TABLE VI: EXPORTS OF SERVICE SUB-SECTORS

\begin{tabular}{|c|c|c|c|c|c|c|}
\hline & \multirow[t]{2}{*}{ Service Sub-sectors } & \multicolumn{2}{|c|}{ Percentage share } & \multicolumn{2}{|c|}{ Growth Rate } & \multirow{2}{*}{$\begin{array}{l}\text { CAGR (2000-01 to } \\
2008-09)\end{array}$} \\
\hline & & $2000-01$ & 2010-11 & $2009-10$ & 2010-11 & \\
\hline 1. & Travel & 21.5 & 11.5 & 8.9 & 28.8 & 15.3 \\
\hline 2. & Transport & 12.6 & 10.7 & -1.2 & 27.7 & 23.8 \\
\hline 3. & Insurance & 1.7 & 1.5 & 11.9 & 22.5 & 23.1 \\
\hline 4. & Government not included elsewhere & 4.0 & 0.4 & 13.4 & 21.3 & -6.2 \\
\hline \multirow[t]{8}{*}{5.} & Miscellenaeous & 60.3 & 75.9 & -12.4 & 42.1 & 30.4 \\
\hline & (a) Software services & 39.0 & 41.7 & 7.4 & 11.6 & 28.2 \\
\hline & (b) Non software services & 21.3 & 34.2 & -40.3 & 113.0 & 33.8 \\
\hline & Of Which: & & & & & \\
\hline & (i) Business Services & 2.1 & 18.1 & -39.4 & 112.4 & 65.3 \\
\hline & (ii) Financial services & 2.1 & 4.9 & -16.6 & 76.3 & 37.5 \\
\hline & (iii) Communication services & 7.0 & 1.2 & -46.6 & 27.2 & 9.2 \\
\hline & Total Services Exports & 100.0 & 100.0 & -9.4 & 38.4 & 26.4 \\
\hline
\end{tabular}

2) India's growth has been led by services as labour productivity levels in services are greater than industry [19].

3) Interestingly, estimates of correlation done by reference [8] between services growth with manufacturing growth show a decline (from 0.77 in period of 1951 to 1965 to 0.30 in 1996 to 2008). No specific correlation was found between services growth and agriculture growth. They state that a small fraction of demand of services is manufacturing driven.

4) The service -led growth is sustainable as average share of service in GDP during 1990s was almost same as the global level for a country with similar per capita GDP [20].

5) The annual growth in services has been at $10 \%$ since 2005/06 that was maintained even during the global economic crisis though there was a fall in overall GDP from $9.3 \%$ in $2007 / 08$ to $6.8 \%$ in $2008 / 09$ [21].

6) The strong growth of services sector has led to stability in India's GDP growth as there has been a decline in volatility of output, decrease in intensity of cyclical fluctuations of GDP and consumption demand is the major growth driver with increased consumption of services [13].

It can be concluded that, the resilience of the Indian economy is due to the resilience of the services sector. There can be an alternative economically sustainable service - led pattern of economic development.

\section{B. Social Sustainability}

'Human capital' rather than 'natural capital' is relatively required more for producing services [22]. economy and growing synergies between industry and services would require high levels of knowledge and skills from the workers rather than unskilled workers [13], [23] Intangible inputs like workers design proficiency, customer relationships and innovative marketing account a major value of most of the products today [23]. Manufacturing - led economic development requires more use of natural resources as compared to services - led pattern. With "industrialization" there is greater use of tangible inputs like land, mineral resources, energy resources, water resources and forest resources.

The human development index (HDI) has been rising consistently since 1980s. It has increased from 0.427 in 1980 to 0.612 in 2007 . This indicates that there has been an improvement in education health and income in India. The per capita income has also registered a rise since 1980. (Table VII). Services growth has led to a decrease in poverty [24]. The coefficient of variation also halved during 1992 to 1999 showing an improvement in quality of growth [20]. Such a growth pattern in the long run may be inclusive in nature. Indian service sector has been generating employment for skilled workers with high perks [25]. Thus, poverty reduction led by services is possible [19] and specifically when a country emphasizes on technology development [26]. Investment in education and upgradation of skills may be a concomitant of service -led growth since there would be greater demand for skilled labour.

\section{Environmental Sustainability}

Services represent the fastest growing sector of the global economy and two-thirds of global output is derived from the service sector. With evolving technologies, services are tradable without any harm to environment and they can be easily transported via satellite without any $\mathrm{CO}_{2}$ emissions. Table VII shows that, there has been a consistent increase in the per capita GDP and HDI value of India since 1980, but per capita $\mathrm{CO}_{2}$ emissions have remained constant (Table VII).

Both the indicators of economic development reveal that India is developing with lesser environment pollution. A comparison between the reference scenario and alternative scenario of International Energy Agency reveals that savings 
of $\mathrm{CO}_{2}$ emissions in India till 2030 will be highest in comparison to the major economies of the world [27]. It is estimated that the ratio of service trade to service output for developing countries has increased much faster than for developed countries [28]. Since there is relatively less use of natural resources in services compared to agriculture and industry, service-led growth will put lesser pressure on the local, regional and global environment [22]. The per capita energy consumption in India decreased from an average of $2.18 \%$ per annum in the decade of 1980 s to $1.86 \%$ per annum in 1990 s and further to $1.68 \%$ per annum in the first half of 2000s. This decrease has been observed despite an increase in the average growth rate of GDP in the corresponding decades from $5.6 \%$ per annum to $5.5 \%$ per annum further to $6.8 \%$ per annum [29].

TABLE VII: $\mathrm{CO}_{2}$ EMISSIONS \& TRENDS IN HDI, AND PER CAPITA GDP IN INDIA

\begin{tabular}{|l|l|l|l|}
\hline & HDI & $\begin{array}{l}\text { Per capita GDP(PPP } \\
\text { Method) (constant } \\
2007 \text { international \$) }\end{array}$ & $\begin{array}{l}\text { Per capita } \\
\mathrm{CO}_{2} \\
\text { emissions } \\
\text { (tonnes) }\end{array}$ \\
\hline 1980 & .427 & 921 & 1 \\
\hline 1990 & .489 & 1279 & 1 \\
\hline 2000 & .556 & 1819 & 1 \\
\hline 2007 & .612 & 2753 & $1 *$ \\
\hline
\end{tabular}

Source: Human Development Report, 2007 and

World Development Reports.* For the year 2005

As the share of services and trade in Environmental Goods and Services (EGS) will increase in GDP there will be a positive relation between exports, environmental sustainability and poverty reduction due to promotion of "2T's" - technology and transferability [26]. UNCTAD has defined EGS as, products that cause significantly less environmental harm at some stage of their life cycle than alternative products that serve the same purpose. OECD classification includes under EGS goods that help to control pollution, cleaner technologies and products that are intrinsically cleaner and more efficient than available alternatives.

Acceleration in GDP growth rate in India during 1990s was also due to increase in private investment. A larger contribution in increase in the average share of machinery in fixed investment by $10 \%$ from 1980 s to 1990 s was from private investment [20]. A coordinated effort between the government agencies, private firms and civic associations is required for focused growth to achieve maximum benefits from the use of limited resources [22].

\section{IMPLICATIONS AND CONCLUSION}

To gainfully employ the growing 'human capital' and improve 'human productivity' there is need to undertake the overdue labour reforms and develop human skills. Fostering of entrepreneurship through development of entrepreneurial skills, financing of entrepreneurial efforts and promotion of networking among potential entrepreneurs and their experienced counterparts with supportive policies in a market-based environment [30] can give an impetus to the GDP growth. Expansion of services in Micro, Small, and
Medium Enterprises (MSME) and Rural Non Farm Economy (RNFE) can help in harnessing the potential of the abundant skilled labour force of the country and reduce the over dependence on agriculture.

Since service sub-sectors that produce ICT or users and those that use skilled labour more intensively, depict highest labour productivity growth [31] emphasis should be laid on technology driven ventures in modern services. A study by [32] concluded that countries with democratic form of government, coupled with relatively low levels of per capita GDP, open trade policies and relatively close to major global financial centres have shown a rapid growth of modern services -finance, communication, computer, technical, legal, advertising and business [32]. India should deregulate key service sub-sectors, like retail, financial services and real estate further to attract FDI and to promote services that are tradable.

For economic and social sustainability there is a need to increase investment in education, entrepreneurship, technology, modern means of communication and transportation and human development coupled by desirable policy reforms. Globalization of services and with transportable, tradable and scalable modern services India would be able to achieve economically, socially and environmentally sustainable service -led growth.

\section{REFERENCES}

[1] S. Kuznets, "Modern economic growth: Findings and reflections," American Economic Review, vol. 63, no. 3, pp. 247-258, 1973

[2] T. S. Papola, "Emerging structure of Indian economy: Implications of growing inter-sectoral imbalances," presented at 88th Conference of Indian Economic Association, Vishakhapatnam, December, pp. 27-29, 2005

[3] J. Gordon and P. Gupta, "Understanding India's services revolution," presented at IMF-NCAER Conference, A Tale of Two Giants: India's and China's Experience with Reform, New Delhi, November 14-16, 2003

[4] R. Banga, "Critical issues in India's service-led growth," Indian Council for Research on International Economic Relations, New Delhi, Working Paper no.171, October 2005

[5] S. Joshi, "From the 'Hindu rate of growth' to 'unstoppable India': has the service sector played a role?" The Service Industries Journal. vol. 30, no. 8, pp. 1299- 1312, July, 2010

[6] Y. Li and B. Yang, "Development path of China and India and the challenges for their sustainable growth," UNU-WIDER, Research Paper no. 2008/37, April, 2008

[7] A. Das, R. Banga, and D. Kumar, "Global economic crisis: Impact and restructuring of the services sector in India," Asian Development Bank Institute, Working Paper series, no. 311, September, 2011

[8] B. Eichengreen and P. Gupta, "The service sector as India's road to economic growth?" Indian Council for Research on International Economic Relations, New Delhi, Working Paper no. 249, April, 2010

[9] B. B. Bhattacharya and A. Mitra, "Excess growth of tertiary sector in Indian Economy: Issues and implications," Economic and Political Weekly, vol. 25, pp. 2445-50, Nov. 3, 1990

[10] S. Hansda, "Sustainability of services-led growth: An input-output analysis of Indian economy," Reserve Bank of India Occasional Papers, vol. 22, no. 1, 2, and 3, pp. 73-118, 2002b

[11] R. Banga and B. Goldar, "Contribution of services to output growth and productivity in Indian manufacturing: Pre and post reforms," Indian Council for Research on International Economic Relations, New Delhi, Working Paper no.139, 2004

[12] G. Kaur, S. Bordoloi, and R.Rajesh, "An empirical Investigation of the inter-sectoral linkages in India," Reserve Bank of India Occasional Papers, vol. 30, no. 1, pp. 29-72, 2009

[13] D. P. Rath and R. Rajesh, "Analytics and implications of services sector growth in Indian economy," The Journal of Income and Wealth, vol. 28, no. 1, pp 1-20, Jan- June 2006

[14] C. Sen, "FDI in the service sector - Propagator of growth for India?" Theoretical and Applied Economics, vol. 18, no. 6, pp. 141-156, 2011 
[15] D. Nikomborirak, "A comparative study of the role of the service sector in the economic, development of China and India," (Revised report) Thailand Development Research Institute, Mimeo, June 19, 2006.

[16] S. Gokarn and G. Gulati, "India: Country growth analysis," Asian Development Bank, October, 2006.

[17] F. Pattanaik and N. C. Nayak, "Employment intensity of service sector in India: Trend and determinants," in Proc. International Conference on Business Economics and Research, Kaula Lampur, 2011, pp. $62-66$

[18] Outward Indian FDI: Recent trends \& emerging issues, Reserve Bank of India, Handbook of Statistics, [Online] March 2012

[19] E. Ghani. (25 Feb. 2010). The service revolution in India. [Online] http://www.voxeu.org/index.php?q=node/4673

[20] A. Virmani, "Indias' economic growth- From socialist to Bhartiya rate of growth," Indian Council for Research on International Economic Relations, New Delhi, Working Paper no. 122, February, 2004

[21] GOI, Economic Survey, 2010-11

[22] T. P. Soubbotina and K. A. Sheram, "Beyond economic growth: Meet the challenges of global development," World Bank Group, 2000

[23] J. J. Thomas, "Indias' rise in the new economy: Implications for labour," ISAS Working Paper no.35, 25, January, 2008

[24] M. Ravallion and G. Dutt, "How important to India,s poor is the sectoral composition of economic growth?" World Bank Economic Review, vol. 10, no. 1, pp. 1-25, 1996

[25] A. S. Sirari and N. S. Bohra, "Foreign Direct Investment (FDI) in India service sector (A study of post liberalization)," International Journal of Economic Research, vol. 2, issue 2, pp. 10-18,2011

[26] K. Kalirajan, V. Anbumozhi, and K. Singh, "Measuring the environmental impacts of changing trade patterns on the poor," Asian Development Bank Institute, Working Paper no.239, August 2010

[27] B. Singh and P. Gupta: "Environment-friendly Energy Policies: A step towards Sustainable Economic Development," published in
Proc.International Conf. on Applied Energy, 21-23 April, Singapore, 2010, pp.1760-1768

[28] World Bank, "Sustaining India's Services Revolution: Access to Foreign Markets, Domestic Reforms and International Negotiations," World Bank Group, South Asia Region, India, 2004

[29] B. Singh and P. Gupta: "Will High Growth Economies have Energy Intensive Growth?" published in Proc. $20092^{\text {nd }}$ Annual Euromed Conf. of EMAB, Managerial and Entrepreneurial developments in the Mediterranean Area, Salerno, Italy October 26-28, 2009, pp. $1510-1524$

[30] K. Lal and R. W. Clement," Economic Development in India: The role of Individual Enterprise (And Entrepreneurial Spirit," Asia-Pacific Development Journal, vol.12. No. 2, pp. 81-99, December, 2005

[31] A. M. Fernandes, "Structure and performance of the service sector in transition economies," The World Bank, 2008

[32] B. Eichengreen and P. Gupta, "The Two Waves of Service Sector Growth,” NBER Working Paper, no. 14968, May, 2009

Bharti Singh is a post graduate in economics. She was awarded the degree of Doctor of Philosophy from the University of Lucknow, India.

She is working as an Associate Professor with the Institute of Management Technology - CDL, Ghaziabad, India. She has over 23 years of teaching experience in a number of premier institutes. She has published a book, Managerial Economics, New Delhi, Excel Books, in 2001. She has a number of published research papers to her credit. Her areas of interest are microeconomics, business environment, international business, consumer behaviour, and higher education. 